This article was downloaded by: [Temple University Libraries]

On: 23 April 2015, At: 00:41

Publisher: Routledge

Informa Ltd Registered in England and Wales Registered Number: 1072954

Registered office: Mortimer House, 37-41 Mortimer Street, London W1T

3J H, UK

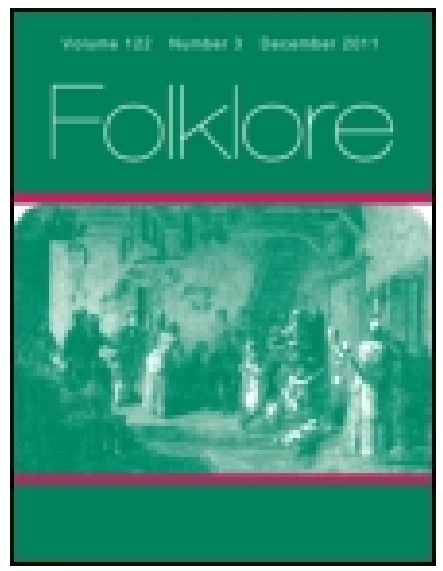

\title{
Folklore
}

Publication details, including instructions for authors and subscription information:

http:// www. tandfonline.com/loi/ rfol20

\section{Folk-Medicine, Nursery-Lore, etc., from the Egean Islands}

W. R. Paton

Published online: 14 Feb 2012.

To cite this article: W. R. Paton (1907) Folk-Medicine, Nursery-Lore, etc., from the Egean Islands, Folklore, 18:3, 329-331, DOI: 10.1080/0015587X.1907.9719783

To link to this article: http:// dx. doi. org/ 10.1080/0015587X.1907.9719783

\section{PLEASE SCROLL DOWN FOR ARTICLE}

Taylor \& Francis makes every effort to ensure the accuracy of all the information (the "Content") contained in the publications on our platform. However, Taylor \& Francis, our agents, and our licensors make no representations or warranties whatsoever as to the accuracy, completeness, or suitability for any purpose of the Content. Any opinions and views expressed in this publication are the opinions and views of the authors, and are not the views of or endorsed by Taylor \& Francis. The accuracy of the Content should not be relied upon and should be independently verified with primary sources of information. Taylor and Francis shall not be liable for any losses, actions, claims, proceedings, demands, costs, expenses, damages, and other liabilities whatsoever or howsoever caused arising directly or indirectly in connection with, in relation to or arising out of the use of the Content.

This article may be used for research, teaching, and private study purposes. Any substantial or systematic reproduction, redistribution, reselling, loan, sub-licensing, systematic supply, or distribution in any form to anyone is 
expressly forbidden. Terms $\&$ Conditions of access and use can be found at http://www.tandfonline.com/page/terms-and-conditions 
A schoolboy at Portishead, East Somerset, calls Cat's Cradle, "The Hammock." He plays the ordinary sequence as far as the Fish figure, which he declares is the Hammock, the previous figures being steps thereto. He could give no further account of the game nor say how he learnt it, except that an epidemic of it (so to speak) had broken out at the school some time previously. His mother, who came from a distant village also in East Somerset, knew the game, but not by the same name: she thought it was called the Chair, or something like that, but could not speak decidedly.

It seems to me possible that the Fish figure may really be the original objective. When compared by the standard of the Oceanic and American string-games, the figures which precede it seem scarcely to merit more than the name of positions, while the final is a figure in the most exacting sense of the word.

W. InNes Pocock.

\section{Folk-Medicine, NURSery-Lore, etc., from the EgeAN ISLANDS.}

RABIES in a dog is caused by its eating a green bird brought by the wind.

Storks' eggs are good for ophthalmia.

For a sore, squeeze a live frog and put it on the sore.

For headache, cut open a live hen and put it on the head.

For the consequences of sudden fright, eat the heart of a live pigeon (still beating), with sugar.

"Agriopetalida" is pounded up and burnt. The ashes are an emmenagogue, and are also used for varicose veins.

"The Virgin's tears" (gum found in certain trees) protects from the bite of scorpions and of the samiomitis, a small lizard which is supposed to bite, but does not as a fact.

Agnus-castus leaves and tamarisk leaves are good for headache. 
Water with three leaves of mint in it in the month of May is good for babies ; it "opens their heart," i.e. cheers them up.

A child must not sleep at midday.

A baby's toes must not be kissed.

Babies must not ride on donkeys, or they will have big teeth.

If a child should be born with a caul, the midwife takes the caul and puts it secretly under the altar of a church, and leaves it there for forty days. It is then good against the evil eye and other things.

Bread may be used instead of a cross or an icon to protect children in the absence of the mother.

To make a baby speak soon, put a young chicken's beak into its mouth.

To stop incontinence of urine, eat roast magpie and drink pig's urine.

To make the hair grow, kill a conger on your head and let its blood remain for six days.

To promote the flow of milk, a woman should take the sound of the grey mullet and throw it over her shoulder.

Love-charm. A mother's milk and a daughter's milk together with a piece of menstruous cloth as a potion.

Remedium Amoris. Take earth from twelve successive steps of the girl. Take it to church, dip a piece of cotton in church-oil and put it in the earth. Put it under the patient's pillow, and he forgets all about the girl.

A woman during her periods may not come into an olive-press, or into a garden, or enter a boat.

Women when they have to kill fowls (which are usually killed by the men) put on their husbands' boots. (Kephalos, Cos.)

Women should not step over dough, nor over their husbands' or children's clothes.

No woman should be present when the dough is being kneaded, except of course the woman who is kneading it. Any other woman who chances to come in must spit on the ground to charm away the evil of her presence, and must leave before the cross is put on the loaves. Otherwise she will "carry away the bread with her." 
It is dangerous to give away dough at night, as it will cause your animals to die. However, if you put some live coals in water, this protects the animals. (Boudroum.)

Sweepings from a house are not to be thrown out at night, as the occupants' souls may be thrown out with them.

A sieve must not be taken out of a house on a starry night, because this will make holes in it.

Eggs must not be set so that the chickens come out in the same month. If this happens, the chickens are delicate. To strengthen them they must be passed through the ring of the door (i.e. the ring used as the handle of a door, and also for padlocking it).

The lizard syglos ( $\left.{ }^{\prime} \lambda \iota 0 s\right)$ can only be killed by a vine-stick.

A water-spirit in the form of a red calf lives in and sometimes comes out of wells.

In the Tupiv' (the week before Lent), the south wind always blows.

To break a water-spout at sea, make a cross with a new black-handled knife and recite the beginning of the Gospel of St. John (see ante, vol. xvi. p. I90).

If anyone sneezes in the presence of a corpse, he or she will soon die.

Cut a piece of cloth from the dress of the person who has sneezed in the presence of a corpse, and put it on the corpse. This will hasten its decay. The belief in Cos is that if anyone sneezes the corpse will not decay. Corpses, it must be explained, are disinterred after three years and the bones re-buried. If the corpse is then found not to have decayed, the deceased is regarded as a vampire.

W. R. Paton.

Agricultural Superstitions in Bellary.

(Communicated by Dr. J. G. Frazer.)

ON the first full moon day in the month of Bhadrapada (September) the agricultural population in the District celebrate a feast called the Jokumara feast, to appease the rain-god. The 